\title{
ANALISIS KELAYAKAN FINANSIAL USAHA AYAM RAS PETELUR DI DESA SODDARA KECAMATAN PASONGSONGAN KABUPATEN SUMENEP
}

\author{
FEASIBILITY ANALYSIS FINANCIAL OF LAYING CHICKEN BUSINESS \\ IN SODDARA VILLAGE, PASONGSONGAN DISTRICT, SUMENEP \\ REGENCY
}

\author{
Moh. Kurdi \\ Management Study Program, Faculty of Economics and Business \\ Wiraraja University, Sumenep, East Java \\ kurdi.em@gmail.com
}

\begin{abstract}
ABSTRAK
Desa Soddara Kecamatan Pasongsongan merupakan salah satu daerah sentra pengembangan ayam ras petelur. Selama ini para pengusaha tidak melakukan analisis kelayakan finansial dari usahanya sehingga belum diketahui sejauh mana tingkat kelayakan ayam ras petelur tersebut. Tujuan dari penelitian ini untuk mengetahui kelayakan finansial (NPV, IRR, dan Net B/C) ayam ras petelur. Lokasi penelitian dilakukan secara sengaja dengan jumlah sampel sebanyak 8 pengusaha.Hasil dari penelitian ini usaha ayam ras petelur di mempunyai nilai NPV >0 yaitu Rp. 91.555.578,74, sedangkan IRR > 16\%, yaitu sebesar 40,32\% serta Net B/C > 1, sebesar 3,16. Sedangkan Payback period usaha ayam ras petelur diketahui 1 tahun 11 bulan 24 hari.
\end{abstract}

Kata Kunci : Kelayakan, Finansial, Ayam Ras Petelur

\section{ABSTRACT}

Soddara Village, Pasongsongan Subdistrict, is one of the centers for developing laying hens. So far, the entrepreneurs have not carried out an analysis of the financial feasibility of their business, so it is not known how far the level of feasibility of chicken laying hens is. The purpose of this study was to determine the financial feasibility (NPV, $I R R$, and Net B / C) of laying hens. The location of the study was done intentionally with a total sample of 8 entrepreneurs. The results of this study laying hens in the business have an NPV value > 0 which is Rp. 91,555,578.74, while IRR>16\%, which is equal to $40.32 \%$ and Net B / C> 1, amounting to 3.16. Whereas the layback business payback period is known to be 1 year 11 months 24 days.

Key Word : Feasibility, Financial, Laying Chicken 


\section{PENDAHULUAN}

Peternakan merupakan usaha yang dilakukan secara konsisten dan teratur disuatu tempat dalam kurun waktu tertentu untuk kepentingan komersial yang mencangkup pada kegiatan membudidayakan ternak, ternak bibit, potong, telur dan jenis usaha ternak lainnya. Ternak dan peternakan memang satu kesatuan. Peternakan adalah sebagai tempat tinggal untuk ternak dalam berproduksi sesuai dengan cara yang digunakan untuk mencapai tujuan yang di harapkan. Dengan demikian, ada keterkaitan antara ternak dengan peternakan. Peternakan terdiri dari tiga fungsi yaitu fungsi produksi, fungsi administrasi, fungsi perluasan dan pengembangan (Saragih dalam Soekardono 2009).

Dalam peternakan, yang merupakan subsistem hulu adalah industri bibit, pakan ternak, obatobatan, alat-alat dan mesin peternakan. Berdasarka jenis yang dihasilkan, subsistem dalam usaha ternak dapat dibagi menjadi usaha ternak ayam ras petelur, usaha ternak potong/pedaging, subsistem hilir meliputi usaha pemotongan hewan,restoran, industri sosis, dan sebagainya. Sedangkan untuk subsistem institusi penunjang dalam kegiatan peterkanakan meliputi Dinas Peternakan, penyuluh, kesehatan hewan, dan sebagainnya (Rasyaf, 2005).

Secara perhitungan ekonomi, pengembangan usaha ternak ayam ras petelur memiliki prospek bisnis menguntungkan dan menjanjikan (Suharno, 2004). Hal ini dapat terjadi bila keadaaan ekonomi dalam kondisi yang stabil dan normal. Namun jika keadaan ekonomi secara gobal mengalami perubahan dan ketidak stabilan, sehingga dapat mempengaruhi keuangan dan permodalan serta kondisi pemasaran hasil produk yang tidak menentu.

Besarnya peluang pemasaran hasil telur merupakan kesempatan yang sangat potensial dan menjanjikan untuk mengembangkan usaha ayam petelur. Hal ini juga karena disebabkan oleh konsumsi protein hewani dalam skala lokal dari tahun ke tahun terus mengalami peningkatan. Keputusan untuk melakukan usaha ayam ras petelur didasarkan pada potensi dan peluang permintaan pasar yang sangat besar (Fadillah, 2005). 


\section{METODE PENELITIAN}

\section{Daerah Penelitian}

Penentuan lokasi penelitian
dilakukan secara sengaja di Desa
Soddara Kecamatan Pasongsongan
dengan pertimbangan bahwa daerah ini
merupakan salah satu daerah
pengembangan usaha ayam ras petelur
di Kabupaten Sumenep. Dengan jumlah
sampel 8 orang pengusaha ayam ras
petelur.

\section{Metode Analisis Data}

Metode yang digunakan dalam menganalisis data pada penelitian ini adalah analisis kelayakan secara finansial usaha ayam ras petelur mengutip pendapat Ibrhim (2009) menggunakan beberapa analisis seperti di bawah ini:

a. NPV (Net Present Value)Umar (2005), digunakan untuk menganalisis nilai sekarang dengan formula sebagai berikut.NPV $=\sum_{t=1}^{n} \frac{B t-C t}{(1+i)^{t}}$

b. Net B/C (Gittinger, 1986), digunakan untuk menganalisis kelayakan usaha ayam ras petelur dengan menggunakan formulasi :
Net

$\mathrm{B} / \mathrm{C}$

$\frac{\sum_{t=1}^{n} \frac{B t-C t}{(1+i y)^{1}}(B t-C t>0)}{\sum_{t=1}^{n} \frac{B t-C t}{(1+i y)^{1}}(B t-C b<0)}$

Net B/C akan didapat apabila paling sedikit salah satu nilai $\mathrm{Bt} / \mathrm{Ct}$ bersifat negatif. Jika tidak maka Net B/C tidak terhingga.

Net $\mathbf{B} / \mathbf{C}=\frac{\text { Jumlah } N P V+}{\text { Jumlah } N P V-}$

c. IRR

Analisis ini digunakan untuk mengetahui kemampuan investasi yang dikeluarkan pada suatu tingkat kenfHhtmgan-yang $N P V 1+[N P V 2]$
didapat tingkat bunga pinjaman (opportunity cost of capital) dengan rumusnya sebagai berikut :

$\mathbf{I R R}=\mathbf{i}_{1}+$ $\left(\mathbf{i}_{2}-\mathbf{i}_{1}\right)$

Dimana :

d. Payback Period Analisis payback period dalam study kelayakan digunakan untuk mengetahui berapa lama usahabaru dapat mengembalikan 
investasi, dengan rumus sebagai berikut:

$$
\mathrm{PBP}=T_{p-1}+\frac{\sum_{i=1}^{n} \bar{I}_{i}-\sum_{i=1}^{n} \bar{B}_{i c p-1}}{\bar{B}_{p}}
$$

\section{HASIL DAN PEMBAHASAN}

\section{Analisis Kelayakan Finansial}

Dalam setiap melakukan usaha pada umumnya membutuhkan dana yang sangat besar dalam menopang keberlangsungan usahanya (Suwarsono, 1994). Dalam melakukan usaha harus benar-benar dilakukan dengan perencanaan dan analisis yang benar, karena tidak sedikit usaha yang setelah dijalankan ternyata tidak menguntungkan. Kegagalan tersebut di karenakan kesalahan dalam melakukan analisis, kesalahan memproyeksi pasar, Tabel 1. Hasil Analisis Kelayakan usaha ayam ras petelur

\begin{tabular}{lr}
\hline Kriteria Ivestasi & DF $16 \%$ \\
\hline NPV & $48.489 .523,17$ \\
IRR & 29,23 \\
Net B/C & 2,15 \\
\hline
\end{tabular}

Sumber : Data diolah 2018

Dari Hasil analisis di atas, menghasilkan keuntungan sebesar Rp. tampak bahwa nilai NPV yang diperoleh pada tingkat bunga 16\% adalah sebesar 48.489.523,17. Hal ini berarti usaha ayam ras petelur akan kesalahan menentukan lokasi dan sebagainya. Maka sangatlan penting untuk melakukan analisis kelayakan pada suatu usaha untuk menghindari kesalahan-kesalahan. Berdasarkan hasil penelitian pada usaha ayam ras di Desa Soddara Kecamatan Pasongasongan,dapat disusun analisis kelayakan usaha sebagai berikut:

Analisis kelayakan finansial usaha ayam ras petelur dimaksudkan untuk memperhatikan usaha ayam ras petelur berdasarkan kriteria investasi, yaitu NPV (Net Present Value), IRR (Internal Rate of Return) dan Net B/C (Net Benefit Cost Ratio), seperti disajikan pada tabel berikut: 48.489.523,17 apabila dihitung dengan nilai sekarang (Present Value). Dengan kata lain usaha ayam ras petelur di Desa Soddara Kecamatan Pasongasongan 
layak untuk dikembangkan karena nilai NPV bernilai positif.

Nilai IRR yang dicapai pada perhitungan di atas sebesar 29,23\%. Artinya usaha ayam ras petelur ini akan memberikan tingkat pengembalian modal sebesar 29,23\%. sehingga pengusaha atau investor merasa lebih baik menginvestasikan modalnya dalam usaha ayam ras petelur ini dari pada mendepositokannya ke Bank yang hanya menghasilkan bunga sebesar 16\%. Hal ini dapat dikatakan bahwa usaha ayam ras petelur layak untuk dikembangkan pada tingkat bunga $16 \%$.

Pada tabel 1 di atas, nilai Net B/C sebesar 2,15 artinya bahwa setiap Rp. 1,00 yang dikeluarkan untuk investasi ini selama 6 tahun akan menghasilkan keuntungan sebesar Rp. 2,15 Suatu proyek disebut layak untuk dikembangkan jika nilai Net B/C Ratio $>1$ dan tidak layak dikembangkan jika nilai $<1$. Dengan demikian usaha ayam ras petelur di lokasi penelitian layak untuk terus dikembangkan karena nilai Net B/C-nya > 1.

Dari perhitungkan kriteria investasi di atas, ternyata semua menunjukkan hasil yang memenuhi syarat, sehingga dapat disimpulkan bahwa usaha ayam ras petelur di Desa Soddara Kecamatan Pasongasongan layak dikembangkan pada tingkat bunga yang berlaku, yaitu $16 \%$.

\section{Analisis Payback Period}

Lamanya jangka waktu pengembalian modal merupakan salah satu pertimbangan bagi seorang investor untuk menanamkan modalnya pada suatu usaha. Seorang investor cendrung lebih suka menanamkan modalnya pada suatu yang mampu mengembalikan investasinya dalam waktu singkat.

Payback period merupakan metode untuk menghitung jangka waktu yang diperlukan utuk membayar kembali seluruh biaya investasi yang telah di keluarkan, yaitu dengan membagi jumlah modal yang diinvestasikan dengan bola tunai yang diperoleh uasahatani sampai tahun dimana biaya investasi tertutupi. Untuk lebih jelasnya berikut ini cara perhitungan paiback period untuk usaha ayam ras petelur.

Dari hasil perhitungan di ketehui, nilai PBP dari usaha ayam ras petelur 1 tahun 4,9 bulan (satu tahun empat bulan dua puluh tujuh hari) artinya modal yang ditanamkan / diinvestasikan oleh peternak untuk 
usaha ayam ras petelur ini akan tertutupi kembali setelah proyek berjalan selama 1 tahun 4,9 bulan .waktu pengembalian selama itu dapat dikatakan tergolong cepat, terutama mengingat benefit yang akan diterima oleh peternak ayam ras petelur cukup besar. Inilah yang menyebabkan banyak petani di Desa Soddara Kecamatan Pasongasongan menjadikan ternak ayam ras petelur sebagai usaha alternatif.

\section{KESIMPULAN DAN SARAN}

\section{Kesimpulan}

Usaha ayam petelur di Desa Soddara

Kecamatan

Pasongasonganmempunyai nilai NPV > 0 yaitu Rp. 48.489.523,17 pada diskon faktor $16 \%$, sedangkan IRR > 16\% yaitu sebesar 29,23\% serta Net B/C > 1, sebesar 2,15. Berdasarkan hasil analisis finansial tersebut, maka Usaha ayam petelur di Desa Soddara Kecamatan Pasongasonganlayak untuk diusahakan. Dan usaha ayam ras petelur di Desa Soddara

Kecamatan

Pasongasonganmempunyai Payback period dari usaha ternak 1 tahun 4 bulan 2 puluh 7 hari.

\section{Saran}

Usaha ayam ras petelur memperoleh perhatian yang difokuskan pada aspek penting:

a. Teknologi yang dikuasai peternak masih tradisional maka diperlukan upaya peningkatan melalui pelatihan bagi peternak.

b. Pembinaan dan peningkatan keterampilan perlu dilakukan terutama aspek kesehatan lingkungan peternakan sehingga memenuhi standart kesehatan.

\section{Daftar Pustaka}

Fadillah, Roni. 2005. Panduan Mengelola Ayam Broiler Komersial. Jakarta: PT. Agromedia Pustaka.

Gittinger, J. Price. 1986. Analisa Ekonomi Proyek-Proyek Pertanian. Penerjemah Slamet Satomo dan Komet Mangiri. Jakarta: Universitas Indonesia Press.

Ibrohim, Yacob. 2009. Studi Kelayakan Bisnis (Edisi Revisi). Jakarta: PT. Renika Cipta.

Umar, Husein. 2005. Metodologi Penelitian. Jakarta: Raja Garfindo

Rasyaf, Muhammad. 2005. Beternak Ayam Petelur. Jakarta: PT. Penebar Swadaya.

Saragih, B. 2000. Agribisnis Berbasis Peternakan. Bogor: Pusat Study Pembangunan IPB. Dalam, Soekardono. 2009. Ekonomi Agribisnis Peternakan Teori 
Dan Aplikasinya. Edisi I.

Jakarta : Akademika Presindo

Suharno, Bambang. 2004. Agribisnis

Ayam Ras. Jakarta: PT. Penebar

Swadaya.

Suwarsono, dan Husnan. 1994. Studi

Kelayakan Proyek. Yogyakarta:

UPP AMP KPN. 